\title{
$\begin{array}{ll}\text { Research Square } & \text { Preprints are preliminary reports that have not undergone peer review. } \\ \text { They should not be considered conclusive, used to inform clinical practice, } \\ \text { or referenced by the media as validated information. }\end{array}$
}

\section{Baseline Health Risk Assessment of Trace Metals in Bivalve Shellfish From Commercial Growing Areas in the Estuaries of Ashtamudi and Vembanad (Kerala, India)}

\author{
Shunmugavel Chinnadurai ( $\sim$ chinnaduraitvl@gmail.com ) \\ CIFT: Central Institute of Fisheries Technology https://orcid.org/0000-0002-5385-7361 \\ Carlos Jose Alexandre de Campos \\ Cawthron Institute \\ Vaithianathan Geethalakshmi \\ CIFT: Central Institute of Fisheries Technology \\ Vasant Kripa \\ CMFRI: Central Marine Fisheries Research Institute \\ Kolliyil Sunil Mohamed \\ CMFRI: Central Marine Fisheries Research Institute
}

Research Article

Keywords: Kerala, Bivalves, Metals, Monitoring, Risk assessment, Target hazard quotient

Posted Date: April 26th, 2021

DOI: https://doi.org/10.21203/rs.3.rs-295735/v1

License: (c) (1) This work is licensed under a Creative Commons Attribution 4.0 International License. Read Full License

Version of Record: A version of this preprint was published at Environmental Science and Pollution Research on July 16th, 2021. See the published version at https://doi.org/10.1007/s11356-021-15284-5. 


\section{Abstract}

Trace metal concentrations were monitored in the yellow clam (Paphia malabarica), green mussel (Perna viridis) and edible oyster (Crassostrea madrasensis) from growing areas in the Ashtamudi and Vembanad estuaries, Kerala. Ranges of mean annual concentrations (mg/kg) were Ni (0.460.65); Co (2.87-3.49); Fe (80.0-119.4); Mn (3.88-9.38); Zn (40.8-76.2); Pb (1.28-2.00); Cu (1.59-4.38). In Ashtamudi, clams had higher mean concentrations of $\mathrm{Ni}, \mathrm{Co}, \mathrm{Fe}, \mathrm{Mn}$ and $\mathrm{Pb}$ than oysters. Mean concentrations of $\mathrm{Ni}, \mathrm{Pb}$ (in all species), $\mathrm{Zn}$ (in clams and mussels) and Cu (in mussels) did not exceed maximum permissible limits mandated by the Food Safety and Standards Authority of India. Mean Mn concentrations exceeded the World Health Organization guideline in the three species while mean Fe concentrations in clams and oysters did not exceed the guideline. Target hazard quotients were generally $\leq 1$, except for a few $\mathrm{Pb}$ results in clams and mussels. Although results suggest no health risk to consumers for the reference doses, daily intakes and elements considered, regular monitoring of trace metals is recommended to maintain consumer protection given increasing anthropogenic and climatic pressures on the shellfish growing areas.

\section{Introduction}

Coastal pollution is a global environmental problem, including accumulation of trace metals in water, sediments and living organisms. While trace metals occur naturally in the environment, growing human activity on the coast is increasing concentrations to levels higher than background in many parts of the world. Anthropogenic sources of trace metals include industrial and municipal wastewater discharges, urban and agricultural runoff, leaching from landfills, and harbour and shipping activities (Förstner and Wittmann, 1983). Bio-accumulation of trace metals by filter-feeding bivalve shellfish above certain levels can pose a health risk to consumers (Abdallah, 2013; Jović and Stanković, 2014). Elevated concentrations may lead to decreased fertility, cellular and tissue damage, cell death, and dysfunction of a variety of organs in consumers (Ribeiro et al., 2002; Damek-Poprawa and Sawicka-Kapusta, 2003). The most toxic metals to shellfish and other marine animals are mercury, cadmium and lead (Pb) (OSPAR, 2015).

India has a long coastline with an estimated total estuarine area of 3.9 million ha, of which 1.24 million ha are considered potentially suitable for shellfish farming (Ayyappan and Diwan, 2006). About 13\% of this area has been allocated to aquaculture (MPEDA 2018). In 2018, the total harvest of bivalve shellfish in the country was ca. 133,000 tonnes (CMFRI, 2019). Production is dominated by clams (76.3\% of the 2018 production) followed by mussels (15.3\%) and oysters (8.4\%) (CMFRI 2019). Estuaries in the State of Kerala together contributed $>80,000$ tonnes of shellfish in 2018 . The main cultivation areas are concentrated in the Vembanad and Ashtamudi, two estuarine systems that open to the central Arabian Sea. Currently, the main species harvested in these estuaries are the green mussel (Perna viridis) and the edible oyster (Crassostrea madrasensis) (Chinnadurai et al., 2014; Mohamed et al., 2016).

The topic of trace metals in commercially harvested shellfish is locally relevant but insufficiently studied in Kerala (George et al., 2013; ShibiniMol et al., 2015; Ragi et al., 2017). The evidence base is still insufficient to assess consumer exposure to trace metals linked to shellfish consumption. The Central Marine Fisheries Research Institute recognises that trace metals in fishery resources present unique risk assessment challenges and identified the need to undertake a surveillance study and health risk assessment to address information gaps. Guidance for good shellfish farming practices requires authorities to assess the sanitary status of the growing areas and implement short-term control measures (e.g. harvest prohibition) if contamination is elevated and areas are deemed unsuitable for health reasons (Mohamed et al., 2019). In this paper, we present new data on trace metals to support these risk assessments, namely concentrations of Nickel (Ni), Cobalt (Co), Iron (Fe), Manganese (Mn), Zinc (Zn), Lead (Pb) and Copper $(\mathrm{Cu})$ in three species of shellfish monitored at farming sites in the Vembanad and Ashtamudi estuaries. We compare the observed results with those previously reported in the literature, including concentration ranges and seasonality. We then discuss whether the observed concentrations exceed nationally and internationally set limits for these substances. Finally, we present data on the daily intake, reference dose and target hazard quotient (THQ) to indicate health risks posed by the trace metals. Baseline risk assessments have been conducted for mercury (Ramasamy et al., 2017) and cadmium (Sruthi et al., 2018; Seethal Lal et al., in press) in these coastal ecosystems and therefore these elements have not been included in our monitoring programme.

\section{Methods}

\subsection{Sample collection}

Samples of the yellow clam (Paphia malabarica), green mussel (Perna viridis) and edible oyster (Crassostrea madrasensis) were collected monthly from growing areas in the Ashtamudi and Vembanad estuaries between June 2012 and December 2014 (Fig. 1). Upon collection, shellfish samples were washed with seawater, placed in cool boxes containing ice packs to keep temperature at $<4^{\circ} \mathrm{C}$ and transported to ICAR - Central Marine Fisheries Research Institute, Kochi for trace metal analyses. All samples were kept in storage for a maximum of $4 \mathrm{~h}$ prior to analyses.

\subsection{Sample preparation and analytical procedures}

In the laboratory, the shellfish were cleaned with Mill-Q water to avoid contamination with sediment. Shellfish flesh was removed from the shells with clean shucking knife and the tissues were homogenised and digested using a microwave digestion system. The shucked soft tissues were then weighed and taken in a vessel for sample digestion. 
A concentration of nitric acid: perchloric acid (9:4) was prepared and $7 \mathrm{ml}$ of combined acid were added to each vessel for pre digestion of samples and left overnight for soaking. After pre-digestion, the samples were digested using a high-performance microwave labstation (ETHOSPLUS) for 40 minutes at $200^{\circ} \mathrm{C}$. After cooling, the samples were diluted and made up to $50 \mathrm{ml}$ using distilled water. The samples were filtered and stored under cool temperature until taken for analysis. The trace metals were analysed by inductively coupled plasma-optical emission spectrometry (ICP-OES) (Optima 4000 DV, Perkin Elmer). Standards of Ni, Co, Fe, Mn, Zn, Pb and Cu were prepared from the respective stock solutions (Merck). 1 \% HNO3 was used as a blank which was prepared in deionised water. The limit of detection of each element was determined by using absorbance of the blank and the standard solution of $1 \mathrm{ppm}$ (Table 1). This ICP-OES method provides quantitative results with high accuracy, is relatively easy to operate (Sneddon and Vincent, 2008) and is routinely used at ICAR.

Table 1

Summary of instrumental parameters used to determine trace metals in shellfish samples.

\begin{tabular}{|llll|}
\hline Trace metal & Wavelength $(\mathrm{nm})$ & Limit of detection $(\mathrm{ppb})$ & Recovery (\%) \\
\hline $\mathrm{Ni}$ & 231.60 & 4.95 & 97.5 \\
$\mathrm{Co}$ & 228.61 & - & 98.1 \\
$\mathrm{Fe}$ & 238.20 & 1.32 & 96.4 \\
$\mathrm{Mn}$ & 257.37 & 0.33 & 100 \\
$\mathrm{Zn}$ & 213.85 & 15.18 & 109 \\
\hline $\mathrm{Cu}$ & 327.39 & 2.60 & 100 \\
\hline $\mathrm{Pb}$ & 220.35 & 9.10 & 92 \\
\hline
\end{tabular}

\subsection{Health risk calculations}

Food consumption data were collected using a quantitative food frequency questionnaire to estimate the shellfish consumption rate for communities. Fifty people with an average body weight of $65 \mathrm{~kg}$ were selected in the study area and asked to complete a questionnaire about their daily shellfish consumption. This information was collected in-person (face-to-face) interviews. Based on the questionnaire results, the estimated mean consumptions of clams, mussels and oysters were 120, 150 and $58 \mathrm{~g} /$ person/day, respectively. It should be noted that shellfish consumption patterns differ both regionally and within specific populations and therefore these values represent local consumption levels.

The health risk assessment comprised the estimated daily intake (EDI) and oral reference dose (RfD) as established by the United States Environmental Protection Agency and the Joint FAO/World Health Organization (WHO) Expert Committee on Food Additives (USEPA, 2011; FAO and WHO, 2013). The RfD was used to evaluate the EDIs of metals in shellfish. The EDI $(\mu \mathrm{g} / \mathrm{kg} /$ day) was calculated using the following equation: EDI = $\mathrm{C}_{\text {shellfish }} \times\left(\mathrm{dc}_{\text {shellfish }} / \mathrm{bw}\right)$, where

$\mathrm{C}_{\text {shellfish }}=$ average trace element concentration in shellfish $(\mathrm{mg} / \mathrm{kg}$ wet weight)

$\mathrm{dc}_{\text {shellfish }}=$ daily shellfish consumption ( $\mathrm{g} /$ day) and

bw $=$ the average body weight $(\mathrm{kg})$ of the target population.

The oral RfDs were $0.04(\mathrm{Cu}) ; 0.004(\mathrm{~Pb}) ; 0.3(\mathrm{Zn}) ; 0.14(\mathrm{Mn}) ; 0.02$ (Ni); 0.03 (Co); and 0.7 (Fe) mg/kg/day (USEPA, 2015). These oral RfDs are based on the safe upper level of trace metal oral intake for an adult with an average body weight of $65 \mathrm{~kg}$. The target hazard quotient (THQ) was calculated using the following equation: THQs = EDI/RfD.

$A T H Q \leq 1.0$ was considered to represent no obvious adverse health effects (and therefore a negligible hazard) as a result of exposure to trace metals from shellfish consumption. A THQ > 1.0 was considered to represent an increasing risk of adverse health effects (Anandkumar et al., 2018).

\subsection{Statistical analyses}

Descriptive statistics (annual and seasonal means and standard deviations) were determined for trace metal concentrations. Analyses of variance followed by post-hoc Tukey HSD tests were carried out to determine if there were any significant differences in mean concentrations between seasons. The seasonal periods considered in the analyses were: pre-monsoon (February-May), monsoon (June-September) and post-monsoon (OctoberJanuary). Statistical tests were assessed at $95 \%$ and $99 \%$ confidence levels. The statistical analyses were carried out using R software.

\section{Results And Discussion}

The yellow-foot clam, the green mussel and the edible oyster are widely harvested for human consumption in Kerala estuaries (Chinnadurai et al., 2016 and 2020). These shellfish provide high quality protein with essential amino acids for maintenance and growth of the human body and are therefore good complements of a healthy diet for local communities (Chakraborty et al., 2016a, 2016b; Joy and Chakraborty, 2017; Krishnan et al., 
2019). Annual and seasonal mean concentrations of $\mathrm{Ni}, \mathrm{Co}, \mathrm{Fe}, \mathrm{Mn}, \mathrm{Zn}, \mathrm{Pb}$ and $\mathrm{Cu}$ in shellfish tissues are presented in Table 2. Health risk threshold concentrations used internationally are summarised in Table 3.

Table 2

Annual and seasonal concentrations of trace metals in shellfish collected in the Ashtamudi and Vembanad estuaries.

\begin{tabular}{|c|c|c|c|c|c|c|c|}
\hline \multirow[b]{2}{*}{ Site (species) } & \multirow[b]{2}{*}{$\begin{array}{l}\text { Trace } \\
\text { metal }\end{array}$} & \multicolumn{6}{|c|}{ Concentration (mg/kg wet weight) (mean \pm standard deviation) } \\
\hline & & Annual & $\begin{array}{l}\text { Pre-monsoon } \\
\text { (February-May) }\end{array}$ & $\begin{array}{l}\text { Monsoon } \\
\text { (June-September) }\end{array}$ & $\begin{array}{l}\text { Post-monsoon } \\
\text { (October-January) }\end{array}$ & F-statistic & $p$-value \\
\hline \multirow{7}{*}{$\begin{array}{l}\text { Ashtamudi Estuary } \\
\text { (P. malabarica) }\end{array}$} & $\mathrm{Ni}$ & $0.59 \pm 0.39$ & $0.52 \pm 0.45$ & $0.69 \pm 0.39$ & $0.56 \pm 0.38$ & 0.88 & 0.432 \\
\hline & Co & $3.42 \pm 2.70$ & $0.95 \pm 0.26$ & $3.99 \pm 2.97$ & $4.84 \pm 2.38$ & 5.50 & 0.014 \\
\hline & $\mathrm{Fe}$ & $119.4 \pm 38.7$ & $156.8 \pm 10.5$ & $102.8 \pm 43.9$ & $103.7 \pm 30.0$ & 6.16 & 0.010 \\
\hline & $\mathrm{Mn}$ & $6.0 \pm 4.79$ & $3.98 \pm 0.50$ & $3.83 \pm 5.82$ & $9.15 \pm 4.81$ & 3.68 & 0.047 \\
\hline & $\mathrm{Zn}$ & $48.1 \pm 43.4$ & $12.5 \pm 2.16$ & $100.6 \pm 12.8$ & $35.5 \pm 37.2$ & 20.4 & 0.000 \\
\hline & $\mathrm{Pb}$ & $2.00 \pm 1.87$ & $3.65 \pm 1.60$ & $1.79 \pm 0.64$ & $1.79 \pm 1.85$ & 2.35 & 0.127 \\
\hline & $\mathrm{Cu}$ & $2.58 \pm 2.55$ & $5.79 \pm 0.74$ & $0.45 \pm 0.43$ & $1.77 \pm 1.93$ & 8.25 & 0.004 \\
\hline \multirow{7}{*}{$\begin{array}{l}\text { Vembanad Estuary } \\
\text { (P. viridis) }\end{array}$} & $\mathrm{Ni}$ & $0.65 \pm 0.39$ & $0.46 \pm 0.38$ & $0.66 \pm 0.44$ & $0.79 \pm 0.03$ & 1.34 & 0.283 \\
\hline & Co & $3.49 \pm 2.72$ & $5.33 \pm 2.02$ & $1.38 \pm 2.19$ & $5.23 \pm 1.36$ & 11.9 & 0.000 \\
\hline & $\mathrm{Fe}$ & $80.0 \pm 35.2$ & $98.5 \pm 43.3$ & $85.5 \pm 35.0$ & $55.5 \pm 7.03$ & 3.14 & 0.064 \\
\hline & $\mathrm{Mn}$ & $9.38 \pm 2.0$ & $11.4 \pm 0.36$ & $9.06 \pm 0.99$ & $8.07 \pm 2.64$ & 7.56 & 0.002 \\
\hline & $\mathrm{Zn}$ & $40.8 \pm 39.0$ & $41.4 \pm 33.0$ & $19.8 \pm 15.6$ & $73.4 \pm 49.6$ & 5.69 & 0.010 \\
\hline & $\mathrm{Pb}$ & $1.28 \pm 1.17$ & $0.40 \pm 0.23$ & $2.24 \pm 1.13$ & $0.52 \pm 0.06$ & 15.3 & 0.000 \\
\hline & $\mathrm{Cu}$ & $1.59 \pm 1.83$ & $0.21 \pm 0.15$ & $3.43 \pm 1.61$ & $0.27 \pm 0.21$ & 14.5 & 0.000 \\
\hline \multirow{7}{*}{$\begin{array}{l}\text { Ashtamudi Estuary } \\
\text { (C. madrasensis) }\end{array}$} & $\mathrm{Ni}$ & $0.46 \pm 0.29$ & $0.59 \pm 0.13$ & $0.49 \pm 0.32$ & $0.42 \pm 0.31$ & 0.91 & 0.409 \\
\hline & Co & $2.87 \pm 2.55$ & $5.32 \pm 0.34$ & $5.77 \pm 1.63$ & $1.17 \pm 1.38$ & 2.99 & 0.063 \\
\hline & $\mathrm{Fe}$ & $91.7 \pm 42.4$ & $129.4 \pm 3.05$ & $50.4 \pm 3.49$ & $97.8 \pm 43.5$ & 10.2 & 0.000 \\
\hline & $\mathrm{Mn}$ & $3.88 \pm 2.18$ & $5.24 \pm 0.69$ & $1.53 \pm 0.98$ & $4.42 \pm 2.12$ & 10.7 & 0.000 \\
\hline & $\mathrm{Zn}$ & $76.2 \pm 40.5$ & $94.9 \pm 2.77$ & $88.0 \pm 39.4$ & $67.2 \pm 44.1$ & 1.67 & 0.202 \\
\hline & $\mathrm{Pb}$ & $1.87 \pm 1.46$ & $0.66 \pm 0.25$ & $2.63 \pm 1.29$ & $1.90 \pm 1.53$ & 3.21 & 0.052 \\
\hline & $\mathrm{Cu}$ & $4.38 \pm 4.29$ & $0.40 \pm 0.18$ & $4.38 \pm 2.87$ & $5.38 \pm 4.73$ & 1.95 & 0.156 \\
\hline
\end{tabular}


Table 3

Mean trace metal concentrations in shellfish from Ashtamudi and Vembanad estuaries and risk threshold concentrations.

\begin{tabular}{|c|c|c|c|c|c|c|c|}
\hline \multirow[t]{2}{*}{ Trace metal } & \multicolumn{3}{|c|}{ Mean concentration (this study) (mg/kg) } & \multicolumn{4}{|c|}{ Threshold concentration (mg/kg) } \\
\hline & P. malabarica & P. viridis & C. madrasensis & WHO ${ }^{1}$ & $\mathrm{EC}^{2}$ & MFR $^{3}$ & FSSAl $^{4}$ \\
\hline $\mathrm{Ni}$ & 0.59 & 0.65 & 0.46 & 2 & - & - & 1.5 \\
\hline $\mathrm{Fe}$ & 119.4 & 80.0 & 91.7 & 100 & - & - & - \\
\hline $\mathrm{Mn}$ & 6.0 & 9.38 & 3.88 & 1 & - & - & - \\
\hline $\mathrm{Zn}$ & 48.1 & 40.8 & 76.2 & 50 & - & 100 & 50 \\
\hline $\mathrm{Pb}$ & 2.00 & 1.28 & 1.87 & 2 & 1.5 & 2 & 2.5 \\
\hline $\mathrm{Cu}$ & 2.58 & 1.59 & 4.38 & 3 & - & 30 & 30 \\
\hline \multicolumn{8}{|c|}{${ }^{1}$ World Health Organization (1993). } \\
\hline \multicolumn{8}{|c|}{${ }^{2}$ European Commission (2006). } \\
\hline \multicolumn{8}{|c|}{${ }^{3}$ Malaysian Food Regulation (1985). } \\
\hline
\end{tabular}

Considering the three shellfish species together, the ranges of mean annual concentrations for individual trace metals were: Ni (0.46-0.65); Co (2.873.49); Fe (80.0-119.4); Mn (3.88-9.38); Zn (40.8-76.2); Pb (1.28-2.00); Cu (1.59-4.38) (all in mg/kg).

Many studies worldwide have reported interspecies differences in mean concentrations of trace metals (e.g. Maanan, 2008; Sakellari et al., 2013). These differences could be due to differences in trophic level (Chen et al., 2000), size (Páez-Osuna and Marmolejo-Rivas, 1990), seasonal factors (Swaileh, 1996; Otchere, 2003; El-Moselhy and Yassien, 2005) and productivity levels in the growing waters (de Mora et al., 2004; Pinto et al., 2015; Lino et al., 2016). In Ashtamudi, clams were more contaminated with trace metals than oysters, except for $\mathrm{Zn}$ and $\mathrm{Cu}$. This result supports the use of clams as indicator species in the shellfish growing area monitoring programme because they occupy the broadest range of habitats and, on average, reflect greater health risk.

Statistically significant seasonal differences were found in mean concentrations for some metals (Table 2). In clams, mean concentrations of Zn and $\mathrm{Cu}$ were significantly higher in the monsoon and pre-monsoon periods, respectively. In mussels, Co and Mn concentrations were significantly higher in the pre-monsoon period and $\mathrm{Pb}$ and $\mathrm{Cu}$ concentrations were significantly higher in the monsoon period. In oysters, Fe and Mn concentrations were significantly higher in the pre-monsoon period.

The seasonality of trace metal concentrations in shellfish have been reported in many studies (Boyden and Phillips, 1981; Swaileh, 1996; El-Moselhy and Yassien, 2005; KrishnaKumari et al., 2006; Maanan, 2008; Belabed et al., 2013; Pinto et al., 2015). Boyden (1974) reported that the metabolic rates of shellfish vary with size, season, and the extent of contamination in the environment. The seasonality in metal concentrations found in the present study could be associated with changes in the weight of soft tissues of the oysters, which in turn are related to their gametogenesis-spawning cycle (Boyden and Phillips, 1981). This is in agreement with many other studies which identify reproductive cycle and food availability as drivers of seasonality in trace metal concentrations (Páez-Osuna et al., 1995; Swaileh, 1996; Otchere, 2003; Maanan, 2008; Pinto et al., 2015). Rainfall intensity is also likely to influence changes in trace metal concentrations in estuaries (Belabed et al. 2013) and is certainly the raise of elevated trace metal concentrations detected during the monsoon period. Elevated pre-monsoon concentrations may be associated with lower water flows and longer resident times of the waters in the estuaries due to the closure of the bar mouths (Krishna Kumari et al. 2006) and the effect of pollution sources on the shoreline near the shellfish growing areas. These sources are well characterised in State of the Environment reports (KSCSTE, 2007).

\subsection{Iron}

Fe was the most abundant trace metal in the three species of shellfish tested. Concentrations of this metal ranged from $37.3 \mathrm{mg} / \mathrm{kg}$ to $195.6 \mathrm{mg} / \mathrm{kg}$. The health risk threshold for this element set out by the WHO is $100 \mathrm{mg} / \mathrm{kg}$ (Table 3). The highest mean annual concentration was detected in clams $(119.4 \pm 38.7 \mathrm{mg} / \mathrm{kg})$ while the lowest was detected in mussels $(80.0 \pm 35.2 \mathrm{mg} / \mathrm{kg})$. Similar results have been reported for Villorita cyprinoides, $P$. viridis and Perna indica from the Vembanad and Ashtamudi estuaries (George et al., 2013; Ragi et al., 2017; Yahiya et al., 2018). In oysters and clams, the gradients of seasonal Fe concentrations were (from the highest to the lowest): pre-monsoon > post-monsoon > monsoon, while in mussels the gradient was: pre-monsoon > monsoon > post-monsoon (Table 2).

The mean Fe concentrations in clams were higher than those reported by KrishnaKumari et al. (2006) (65.7-260 $\mu \mathrm{g} / \mathrm{g}$ dry wt) but lower than those detected Parvez Al-Usmani et al. (2015) in Goa (1,205-2,506 ppm, dw). Fe concentrations in mussels were lower than those reported by Rivonker and Parulekar (1998) (1,900-4,200 g/g dry wt) and Parvez Al-Usmani et al. (2015) (1,906-2,802 ppm, dw) in Goa, by Krishnakumar et al. (2006) from 
Karwar, Karnataka (96.4-286.5 $\mu \mathrm{g} / \mathrm{g}$ wet wt) and by Satheeswaran et al. (2019) in the Vellar Estuary, East coast of India (132 mg/kg wet wt). Fe concentrations in mussels were however similar to those found at sites along the Calicut and Mangalore coasts of India (15.7-90.6 mg/kg wet wt) (Krishnakumar et al., 2006; Sasikumar et al., 2006; Sasikumar et al., 2011). Fe concentrations in oysters (C. madrasensis) were lower than those reported by Parvez Al-Usmani et al. (2015) in Saccostrea cucullata from Goa, west coast of India. The iron concentration recorded in C. madrasensis in the present study was similar to those of S. cucullata from Bombay coast (KrishnaKumari et al., 1992) (312 $\pm 160 \mathrm{mg} / \mathrm{kg}$ dry wt) and in Ostrea edulis from east coast of India (80.49 mg/kg wet wt) (Satheeswaran et al. 2019).

\subsection{Zinc}

$\mathrm{Zn}$ was the second most abundant trace metal detected in the shellfish samples. Zn concentrations ranged widely from $10.0 \mathrm{mg} / \mathrm{kg}$ and $149.8 \mathrm{mg} / \mathrm{kg}$. The highest mean annual concentration was detected in oysters $(76.2 \mathrm{mg} / \mathrm{kg}$ ) and the lowest was detected in mussels (40.8 mg/ $\mathrm{kg})$. These concentrations are similar to those reported in other studies undertaken in India (8.7-151.2 mg/kg) (Lakshmanan and Nambisan, 1983; Rivonker and Parulekar, 1998; Krishnakumar et al., 2006; Sasikumar et al., 2006, 2011; Ragi et al., 2017). However, some studies have found comparatively lower concentrations of $\mathrm{Zn}$ in shellfish from sites on the East coast of India (Senthilnathan et al., 1998; Sarkar et al., 2008; Asha et al., 2010; Satheeswaran et al., 2019). The maximum permissible limit for this element by both the FSSAl and WHO is $50 \mathrm{mg} / \mathrm{kg}$ (Table 3). This limit is higher than the mean annual concentrations detected in clams $(48.1 \mathrm{mg} / \mathrm{kg})$ and mussels $(40.8 \mathrm{mg} / \mathrm{kg})$ but lower than the mean detected in oysters $(76.2 \mathrm{mg} / \mathrm{kg})$. Therefore, there is no apparent Zn risk from consuming clams from Ashtamudi or mussels from Vembanad.

\subsection{Manganese}

Mn concentrations ranged from 0.32 and $14.6 \mathrm{mg} / \mathrm{kg}$. The WHO sets out a risk threshold of $1 \mathrm{mg} / \mathrm{kg}$ for this element (Table 3 ). The highest concentration was found in clams $(14.6 \mathrm{mg} / \mathrm{kg})$ and the lowest in oysters $(0.32 \mathrm{mg} / \mathrm{kg})$ (Table 2). Similar concentrations have been reported in $V$. cyprinoides from the Vembanad Estuary (Babukutty and Chacko, 1992). Mn concentrations in clams, mussels and oysters from the Ashtamudi and Vembanad estuaries were similar to those found in oysters from Bombay coast (28 $\pm 21 \mathrm{mg} / \mathrm{kg}$ dry wt) (Krishna Kumari et al. 1992) and in mussels and oysters from Karnataka coast (6.67 \pm 0.24 and $6.80 \pm 0.76 \mathrm{mg} / \mathrm{kg}$ wet wt) (Krishnakumar et al., 1998; Krishnakumar et al., 1990 ; Sasikumar et al., 2006), in clams from the Gulf of Mannar (27.88 $\pm 3.7 \mathrm{mg} / \mathrm{kg}$ dry wt) (Asha et al. 2010), in mussel from the Vellar estuary, East coast of India (13.08 $\mathrm{mg} / \mathrm{kg}$ wet wt) (Satheeswaran et al. 2019), in clams from Sunderban (32.02 mg/kg dry wt) (Saha et al., 2006) and in oysters from Andaman coastal waters (3.88 $\pm 0.27 \mathrm{mg} / \mathrm{kg}$ wet wt) (Seetharaman et al. 2015).

\subsection{Copper}

Cu concentrations varied widely between species. In oysters, Cu concentrations ranged from 0 to $13.1 \mathrm{mg} / \mathrm{kg}$ while in clams and mussels Cu concentrations ranged from 0 to $6.95 \mathrm{mg} / \mathrm{kg}$ and from 0 to $4.67 \mathrm{mg} / \mathrm{kg}$, respectively. The FSSAl prescribes a limit of $30 \mathrm{mg} / \mathrm{kg}$ (Table 3 ) which is relatively higher than the maxima detected in this study. The WHO estimated daily Cu intakes via food as 2-30 mg/kg (WHO, 1993). This implies no Cu risk from consuming the shellfish from the Ashtamudi and Vembanad estuaries. Cu concentrations detected in this study were generally lower than those previously reported for sites in the Ashtamudi and Vembanad estuaries (Lakshmanan and Nambisan, 1983; Babukutty and Chacko, 1992; Kaladharan et al., 2005; George et al., 2013) and similar to those reported by ShibiniMol et al. (2015) and Ragi et al. (2017). A few studies have however reported higher concentrations in shellfish from the Ashtamudi and Vembanad estuaries (Lakshmanan, 1988; Sivaperumal et al., 2007).

\subsection{Lead}

$\mathrm{Pb}$ concentrations ranged from 0 to $5.86 \mathrm{mg} / \mathrm{kg}$ in clams, from 0 to $3.67 \mathrm{mg} / \mathrm{kg}$ in mussels, and from 0 to $4.27 \mathrm{mg} / \mathrm{kg}$ in oysters. The maximum permissible limit for Pb set by the WHO and MFR is $2 \mathrm{mg} / \mathrm{kg}$ (Table 3). According to FSSAl, Pb concentrations in shellfish should not exceed 2.5 $\mathrm{mg} / \mathrm{kg}$ (Table 3). Mean annual concentrations found in this study were $2 \mathrm{mg} / \mathrm{kg}$ in clams from Ashtamudi, $1.28 \mathrm{mg} / \mathrm{kg}$ in mussels from Vembanad, and $1.87 \mathrm{mg} / \mathrm{kg}$ in oysters from Ashtamudi and are therefore below the FSSAI limit. Concentrations were however generally higher than those reported previously for these estuaries (0.22-6.63 mg/kg) (Lakshmanan and Nambisan, 1983; Babukutty and Chacko, 1992; Kaladharan et al., 2005; Sivaperumal et al., 2007; George et al., 2013; ShibiniMol et al., 2015; Ragi et al., 2017). Higher concentrations than those presented here have been reported in clams from the Mandovi Estuary (Goa) (KrishnaKumari et al., 2006; Patra et al., 2019).

\subsection{Nickel}

Ni concentrations ranged from 0.10 to $1.04 \mathrm{mg} / \mathrm{kg}$ in clams, from 0.10 to $1.42 \mathrm{mg} / \mathrm{kg}$ in mussels, and from 0.43 to $0.95 \mathrm{mg} / \mathrm{kg}$ in oysters. The maximum permissible limits for Ni prescribed by the WHO and FSSAI are 2 and $1.5 \mathrm{mg} / \mathrm{kg}$, respectively (Table 3). Therefore, Ni concentrations in mussels were well below these thresholds. Ni concentrations in mussels from northern Vembanad Estuary were higher than those in clams and oysters from the Ashtamudi Estuary. This result is consistent with results published by Yap et al. (2016) and support the assumption that most Ni contamination found in the Vembanad is related to anthropogenic sources.

The Ni concentrations in shellfish found in this study were comparable to those reported previously for sites in the Ashtamudi and Vembanad estuaries and other sites on the east and west coasts of India (Sankar et al., 2006; Sasikumar et al., 2011, 2006; Asha et al., 2010; Satheeswaran et al., 2019). However, the mean Ni concentration in clam (V. cyprinoides) from Vembanad estuary reported by ShibiniMol et al. (2015) was five times higher than Ni concentrations recorded for this species in this study, while concentrations reported by Ragi et al. (2017) were two times lower compared to those reported here. 


\subsection{Cobalt}

Co concentrations ranged from 0.33 to $9.42 \mathrm{mg} / \mathrm{kg}$ in clams, from 0.18 to $7.53 \mathrm{mg} / \mathrm{kg}$ in mussels, and from 0.19 to $7.20 \mathrm{mg} / \mathrm{kg}$ in oysters. The WHO has estimated daily Co intakes via food of $5-45 \mu \mathrm{g} /$ day $(\mathrm{WHO}, 1993)$. The concentrations of Co found in shellfish from the Ashtamudi and Vembanad are well below this limit. However, Co concentrations are higher than those reported by Sivaperumal et al. (2007), George et al. (2013) and Ragi et al. (2017) for the Ashtamudi and Vembanad estuaries. Lower concentrations (6.58 mg/kg wet wt) were reported by Babukutty and Chacko (1992).

\subsection{Health risk assessment}

The oral RfD ranged from 0.004 (Pb in clams and oysters; $\mathrm{Zn}$ in mussels) to 0.700 (Fe in the three species) (Table 4). Mean annual EDIs ranged from $0.071(\mathrm{Ni})$ to $14.330(\mathrm{Fe})$ in clams, from $0.098(\mathrm{Ni})$ to $12.010(\mathrm{Fe})$ in mussels, and from $0.027(\mathrm{Ni})$ to 5.323 (Fe) in oysters (all in mg/day). The THQ in clams ranged from $0.044(\mathrm{Mn})$ to $1.005(\mathrm{~Pb})$ in clams, from $0.081(\mathrm{Ni})$ to $0.800(\mathrm{~Pb})$ in mussels, and from $0.022(\mathrm{Ni})$ to $0.452(\mathrm{~Pb})$ in oysters. THQs varied between seasons and were generally higher in pre-monsoon and monsoon periods.

Table 4

Estimated oral reference doses, daily intakes and target hazard quotients associated with consumption of shellfish from the Ashtamudi and Vembanad estuaries.

\begin{tabular}{|c|c|c|c|c|c|c|c|c|c|c|}
\hline \multirow[t]{2}{*}{ Site (species) } & \multirow{2}{*}{$\begin{array}{l}\text { Trace } \\
\text { Metal }\end{array}$} & \multirow{2}{*}{$\begin{array}{l}\text { oral } \\
\text { Reference } \\
\text { Dose } \\
\text { (RfD) } \\
(\mathrm{mg} / \mathrm{kg} / \text { day) }\end{array}$} & \multicolumn{4}{|c|}{ Estimated daily intake (EDI, mg/day) } & \multicolumn{4}{|c|}{ Target Hazard Quotient (THQ) } \\
\hline & & & $\begin{array}{l}\text { Pre- } \\
\text { monsoon } \\
\text { (February- } \\
\text { May) }\end{array}$ & $\begin{array}{l}\text { Monsoon } \\
\text { (June- } \\
\text { September) }\end{array}$ & $\begin{array}{l}\text { Post- } \\
\text { monsoon } \\
\text { (October- } \\
\text { January) }\end{array}$ & Annual & $\begin{array}{l}\text { Pre- } \\
\text { monsoon } \\
\text { (February- } \\
\text { May) }\end{array}$ & $\begin{array}{l}\text { Monsoon } \\
\text { (June- } \\
\text { September) }\end{array}$ & $\begin{array}{l}\text { Post- } \\
\text { monsoon } \\
\text { (October- } \\
\text { January) }\end{array}$ & Annual \\
\hline \multirow{7}{*}{$\begin{array}{l}\text { Ashtamudi } \\
\text { Estuary }(P . \\
\text { malabarica) }\end{array}$} & $\mathrm{Cu}$ & 0.040 & 0.695 & 0.054 & 0.212 & 0.312 & 0.290 & 0.023 & 0.089 & 0.129 \\
\hline & $\mathrm{Pb}$ & 0.004 & 0.438 & 0.077 & 0.215 & 0.241 & 1.825 & 0.320 & 0.895 & 1.005 \\
\hline & $\mathrm{Zn}$ & 0.300 & 1.501 & 8.273 & 2.921 & 4.100 & 0.083 & 0.460 & 0.162 & 0.228 \\
\hline & $\mathrm{Mn}$ & 0.140 & 0.478 & 0.259 & 0.364 & 0.367 & 0.057 & 0.031 & 0.043 & 0.044 \\
\hline & $\mathrm{Ni}$ & 0.020 & 0.064 & 0.084 & 0.068 & 0.071 & 0.053 & 0.070 & 0.057 & 0.059 \\
\hline & Co & 0.030 & 0.115 & 0.479 & 0.582 & 0.410 & 0.064 & 0.266 & 0.323 & 0.228 \\
\hline & $\mathrm{Fe}$ & 0.700 & 18.81 & 12.33 & 12.45 & 14.33 & 0.448 & 0.294 & 0.297 & 0.341 \\
\hline \multirow{7}{*}{$\begin{array}{l}\text { Vembanad } \\
\text { Estuary ( } P . \\
\text { viridis) }\end{array}$} & $\mathrm{Cu}$ & 0.040 & 0.033 & 0.476 & 0.042 & 0.239 & 0.014 & 0.198 & 0.018 & 0.099 \\
\hline & $\mathrm{Pb}$ & 0.004 & 0.062 & 0.336 & 0.080 & 0.192 & 0.256 & 1.400 & 0.331 & 0.800 \\
\hline & $\mathrm{Zn}$ & 0.300 & 3.500 & 1.884 & 11.019 & 4.952 & 0.194 & 0.105 & 0.612 & 0.275 \\
\hline & $\mathrm{Mn}$ & 0.140 & 1.725 & 1.359 & 1.212 & 1.407 & 0.205 & 0.162 & 0.144 & 0.168 \\
\hline & $\mathrm{Ni}$ & 0.020 & 0.071 & 0.099 & 0.120 & 0.098 & 0.059 & 0.083 & 0.100 & 0.081 \\
\hline & Co & 0.030 & 0.801 & 0.207 & 0.785 & 0.524 & 0.445 & 0.115 & 0.436 & 0.291 \\
\hline & $\mathrm{Fe}$ & 0.700 & 14.78 & 12.84 & 8.339 & 12.01 & 0.352 & 0.306 & 0.199 & 0.286 \\
\hline \multirow{7}{*}{$\begin{array}{l}\text { Vembanad } \\
\text { Estuary }(C . \\
\text { madrasensis })\end{array}$} & $\mathrm{Cu}$ & 0.040 & 0.139 & 0.254 & 0.312 & 0.255 & 0.058 & 0.106 & 0.130 & 0.106 \\
\hline & $\mathrm{Pb}$ & 0.004 & 0.038 & 0.153 & 0.110 & 0.108 & 0.160 & 0.636 & 0.459 & 0.452 \\
\hline & $\mathrm{Zn}$ & 0.300 & 5.504 & 5.109 & 3.898 & 4.425 & 0.306 & 0.284 & 0.217 & 0.246 \\
\hline & $\mathrm{Mn}$ & 0.140 & 0.304 & 0.089 & 0.256 & 0.225 & 0.036 & 0.011 & 0.031 & 0.027 \\
\hline & $\mathrm{Ni}$ & 0.020 & 0.034 & 0.028 & 0.024 & 0.027 & 0.029 & 0.024 & 0.020 & 0.022 \\
\hline & Co & 0.030 & 0.309 & 0.335 & 0.068 & 0.166 & 0.171 & 0.186 & 0.038 & 0.092 \\
\hline & $\mathrm{Fe}$ & 0.700 & 7.505 & 2.927 & 5.675 & 5.323 & 0.179 & 0.070 & 0.135 & 0.127 \\
\hline
\end{tabular}

Annual and seasonal THQs due to intake of trace metals through shellfish consumption in coastal populations are presented in Table 4. Overall, the THQs were $\leq 1$, except for two Pb results in P. malabarica in the pre-monsoon period (1.82) and annual (1.00) (Table 2). Similarly, the THQs in $P$. viridis were low, characteristic of products acceptable for human consumption, except for the Pb in the monsoon season (1.4) (Table 2), indicating no health hazard in local population due to mussel consumption. In $C$. madrasensis, THQs were $\leq 1$ for all metals and in all seasons, also indicating no health hazard from oyster consumption to consumers.

\subsection{Comparison with previous studies}


Accumulations of metals in shellfish are generally associated with site-specific metal bioavailability, filtering capacity, sexual maturity and body size and their position in water column (McConchie and Lawrance, 1991; Chen et al., 2000). Table 5 compares concentrations of trace metals in shellfish detected in the present study with those reported in other recent studies performed in the same study areas. Generally, the results indicate greater concentrations of $\mathrm{Ni}$ and $\mathrm{Fe}$ in the Vembanad Estuary than in the Ashtamudi Estuary. Comparing data reported only for Ashtamudi, the present study found higher concentrations of $\mathrm{Co}, \mathrm{Fe}, \mathrm{Mn}$ and $\mathrm{Pb}$ than previous studies. For Vembanad Estuary, concentrations of Fe and Mn were also higher in the present study. However, on an individual trace metal level, the concentrations are not markedly higher/lower than those reported previously suggesting no substantial changes in the amounts of metal bioavailability over time in the study areas.

Table 5

Concentrations of trace metals in shellfish from the Ashtamudi and Vembanad estuaries reported in the present and previous recent studies.

\begin{tabular}{|c|c|c|c|c|c|c|c|c|c|c|}
\hline \multicolumn{11}{|c|}{ Concentration (mg/kg) } \\
\hline Site & Species & $\begin{array}{l}\text { Sampling } \\
\text { period }\end{array}$ & $\mathrm{Ni}$ & Co & $\mathrm{Fe}$ & $\mathrm{Mn}$ & $\mathrm{Zn}$ & $\mathrm{Pb}$ & $\mathrm{Cu}$ & Reference \\
\hline \multirow{6}{*}{$\begin{array}{l}\text { Ashtamudi } \\
\text { Estuary }\end{array}$} & Perna viridis & 2003 & - & - & - & - & 88.81 & 14.91 & 4.20 & Varshney (2003) \\
\hline & Villorita cyprinoides & ns & 0.47 & 0.22 & 12.76 & 0.97 & 13.15 & 0.35 & 2.40 & Ragi et al. (2017)* \\
\hline & Perna viridis & ns & 0.20 & 0.25 & 9.97 & 0.79 & 14.14 & 0.31 & 1.71 & Ragi et al. (2017)* \\
\hline & Perna indica & 2017 & - & - & 12.93 & - & - & 0.87 & - & Yahiya et al. (2018) \\
\hline & Paphia malabarica & $2012-2014$ & 0.59 & 3.42 & 119.4 & 6.0 & 48.1 & 37.2 & 1.85 & Present study \\
\hline & $\begin{array}{l}\text { Crassostrea } \\
\text { madrasensis }\end{array}$ & $2012-2014$ & 0.46 & 2.87 & 91.7 & 3.88 & 76.2 & 1.87 & 4.38 & Present study \\
\hline \multirow[t]{7}{*}{$\begin{array}{l}\text { Vembanad } \\
\text { Estuary }\end{array}$} & Sunetta scripta & 1990-1998 & - & - & - & & 3.74 & 0.5 & 0.61 & $\begin{array}{l}\text { Kaladharan et al. } \\
(2005)^{\star}\end{array}$ \\
\hline & Perna viridis & 2003 & 0.89 & 0.17 & - & 0.43 & 37.7 & 0.37 & 11.7 & $\begin{array}{l}\text { Sivaperumal et al. } \\
(2007)\end{array}$ \\
\hline & Villorita cyprinoides & 2003 & 0.76 & 0.06 & - & 0.46 & 18.5 & 0.32 & 3.9 & $\begin{array}{l}\text { Sivaperumal et al. } \\
(2007)\end{array}$ \\
\hline & Villorita cyprinoides & $2007-2008$ & & & - & - & 55.1 & 1.17 & 3.22 & $\begin{array}{l}\text { Raveenderan and } \\
\text { Sujatha (2011) }\end{array}$ \\
\hline & Villorita cyprinoides & 2010-2011 & 0.56 & 1.07 & 67.69 & - & 3.83 & 0.12 & 0.32 & George et al. (2013)* \\
\hline & Villorita cyprinoides & 2013 & 3.79 & - & - & - & 22.13 & 1.15 & 2.72 & $\begin{array}{l}\text { ShibiniMol et al. } \\
(2015)^{\star}\end{array}$ \\
\hline & Perna viridis & $2012-2014$ & 0.65 & 3.49 & 80.0 & 9.38 & 40.8 & 1.28 & 1.59 & Present study \\
\hline
\end{tabular}

\section{Conclusions}

Essential trace metals present in shellfish such as Fe, Cu and Zn play important roles in biological systems (Hogstrand and Haux, 1991), whereas nonessential metals such as $\mathrm{Pb}$ and $\mathrm{Cd}$ are usually considered as potent toxins. In the present study, we quantified concentrations of $\mathrm{Ni}$, Co, $\mathrm{Mn}$, $\mathrm{Pb}$, $\mathrm{Cu}$, Zn and Fe in three species of shellfish (clams $P$. malabarica; mussels $P$. viridis; oysters $C$. madrasensis) sampled from the Ashtamudi and northern Vembanad estuaries, the most important cultivation sites in Kerala. We estimated the daily intake of trace metals due to shellfish consumption for an adult as compared to the oral reference dose recommended by the USEPA (2015). The observed concentrations for most of the trace metals were below the health risk thresholds set out by national and international guidelines and therefore consumption of shellfish from the study sites does not pose a health risk to consumers concerning these elements. However, some of the observed concentrations of Fe and $\mathrm{Zn}$ were slightly higher than the permissible limits. While this study adds baseline information on the range of trace metal concentrations that may be found in commercially harvested shellfish, further studies are needed to characterise exposure pathways and identify sensitive (sub) populations.

\section{Abbreviations}

THQ, target hazard quotient; EDI, estimated daily intake; RfD, oral reference dose; FSSAl, Food Safety and Standards Authority of India; WHO, World Health Organization; EC, European Commission; MFR, Malaysian Food Regulation.

\section{Declarations}




\section{Acknowledgements}

S. Chinnadurai gratefully acknowledges fellowship received from the National Agricultural Innovation Project (NAIP) of the World Bank (P. Code 2000035102). The authors are grateful to the Director of the Central Marine Fisheries Research Institute (ICAR-CMFRI) for logistical and technical support and advice during this study. Thanks also due to the Director of the Central Institute of Fisheries Technology (ICAR-CIFT) and Head of the Quality Assurance and Management Division for the trace metal analyses.

\section{Author contributions}

SC: Conceptualization, Methodology, Validation, Investigation, Formal analysis, Writing - original draft, Writing - review and editing. CJAC: Conceptualization, Writing - review and editing. VG: Statistical analysis, Writing - review and editing. VK: Conceptualization, Funding acquisition. KSM: Conceptualization, Writing - review and editing, Project administration

\section{Ethics approval and consent to participate: Not applicable}

Funding: This work was financially supported by the ICAR-NAIP (National Agricultural Innovation Project), Ministry of Agriculture and Farmer Welfare, Government of India, New Delhi.

Data Availability: The data that support the findings of this study are available on request from the corresponding author.

Declaration of interests: The authors declare that they have no known competing financial interests or personal relationships that could have appeared to influence the work reported in this paper.

Consent for Publication: All of the authors have read and approved the paper for submission of publication.

\section{References}

1. Abdallah, M.A.M., 2013. Bioaccumulation of heavy metals in mollusca species and assessment of potential risks to human health. Bull. Environ. Contam. Toxicol. 90, 552- doi:10.1007/s00128-013-0959-x

2. Anandkumar, A., Nagarajan, R., Prabakaran, K., Han, C., Rajaram, R., 2018. Human health risk assessment and bioaccumulation of trace metals in fish species collected from the Miri coast, Sarawak, Borneo. Mar. Pollut. Bull. 133, 655-663. doi:10.1016/j.marpolbul.2018.06.033

3. Asha, P., Krishnakumar, P., Kaladharan, P., Prema, D., Diwakar, K., Valsala, K., Bhat, G., Heavy metal concentration in sea water, sediment and bivalves off Tuticorin. J. Mar. Biol. Assoc. India 52, 48-54.

4. Ayyappan, S., Diwan, A.D., 2006. Fisheries research and development in India. Fish. Chimes, 26 (1), 19-23.

5. Babukutty, Y., Chacko, J., 1992. Trace metals in an estuarine bivalve from the southwest coast of India. Ambio 21, $292-296$. doi:10.5363/tits.6.3_37

6. Belabed, B.E., Laffray, X., Dhib, A., Fertouna-Belakhal, M., Turki, S., Aleya, L., 2013. Factors contributing to heavy metal accumulation in sediments and in the intertidal mussel Perna perna in the Gulf of Annaba (Algeria). Mar. Pollut. Bull. 74, 477-489. doi:10.1016/j.marpolbul.2013.06.004

7. Boyden, C.R., 1974. Trace element content and body size in molluscs. Nature 251.

8. Boyden, C.R., Phillips, D.J.H., 1981. Seasonal variation and inherent variability of trace elements in oysters and their implications for indicator studies. Mar. Ecol. Prog. Ser. 5, 29-40. doi:10.3354/meps005029

9. Chakraborty, K., Chakkalakal, S.J., Joseph, D., Asokan, P.K., Vijayan, K.K., 2016a. Nutritional and antioxidative attributes of green mussel (Perna viridis L.) from the Southwestern Coast of India. J. Aquat. Food Prod. Technol. 25, 968-985. doi:10.1080/10498850.2015.1004498

10. Chakraborty, K., Chakkalakal, S.J., Joseph, D., Joy, M., 2016b. Nutritional composition of edible oysters (Crassostrea madrasensis L.) from the Southwest Coast of India. J. Aquat. Food Prod. Technol. 25, 1172-1189. doi:10.1080/10498850.2015.1039682

11. Chen, C.Y., Stemberger, R.S., Klaue, B., Blum, J.D., Pickhardt, P.C., Folt, C.L., 2000. Accumulation of heavy metals in food web components across a gradient of lakes. Limnol. Oceanogr. 45, 1525-1536.

12. Chinnadurai, S., Mohamed, K.S., Venkatesan, V., Sharma, J., Kripa, V., 2014. Depuration of bacterial populations in the Indian backwater oyster Crassostrea madrasensis (Preston, 1916): Effects on surface and bottom held oysters. J. Shellfish Res. 33, 409-414.

13. Chinnadurai, S., Mohamed, K.S., Sharma, J., Venkatesan, V., Kripa, V., 2016. Assessment of bio-accumulation of bacteria in oysters from shellfish growing waters in Ashtamudi Lake (Kerala, India): A RAMSAR wetland. Reg. Stud. Mar. Sci. 7, 118-122. doi:10.1016/j.rsma.2016.05.016

14. Chinnadurai, S., Campos, C.J.A., Geethalakshmi, V., Sharma, J., Kripa, V., Mohamed, K.S., Microbiological quality of shellfish harvesting areas in the Ashtamudi and

15. Vembanad estuaries (India): Environmental influences and compliance with international standards. Mar. Pollut. Bull. $156,111255$. doi:10.1016/j.marpolbul.2020.111255

16. CMFRI., 2019. Central Marine Fisheries Research Institute Annual Report 2018-19. Kochi, Kerala, India. Retrieved from http://210.212.232.211:8080/jspui/flipdocs/267/mobile/index.html\#p=8. 
17. Damek-Poprawa, M., Sawicka-Kapusta, K., 2003. Damage to the liver, kidney, and testis with reference to burden of heavy metals in yellow-necked mice from areas around steelworks and zinc smelters in Poland. Toxicology, 186, 1-10.EC, 2006.

18. COMMISSION REGULATION (EC) No 1881/2006 of 19 December 2006 setting maximum levels for certain contaminants in foodstuffs. Off. J. Eur. Union L 364, 5-24.

19. El-Moselhy, K.M., Yassien, M.H., 2005. Accumulation patterns of heavy metals in venus clams, Paphia undulata (Born, 1780) and Gafrarium pectinatum (Linnaeus, 1758), from Lake Timsah, Suez Canal, Egypt. Egypt. J. Aquat. Res. 31, 13-28.

20. FAO/WHO, 2013. Evaluation of certain food additives and contaminants. Seventy-third report of the Joint FAO/WHO Expert Committee on Food Additives. WHO Technical Report Series 960. https://apps.who.int/iris/bitstream/handle/10665/44515/WHO_TRS_960_eng.pdf.

21. Förstner, U., Wittmann, G.T., 1983. Metal pollution in the aquatic environment. Springer-Verlag, Berlin, Heidelberg, New York, Tokyo.

22. FSSAl, 2011. Food safety and standards (contaminants, toxins and residues) regulations, 2011. https://www.fssai.gov.in/upload/uploadfiles/files/Compendium_Contaminants_Regulations_20_08_2020.pdf

23. George, R., Martin, G.D., Nair, S.M., Chandramohanakumar, N., 2013. Biomonitoring of trace metal pollution using the bivalve molluscs, Villorita cyprinoides, from the Cochin backwaters. Environ. Monit. Assess. 185, 10317-10331. doi:10.1007/s10661-013-3334-9

24. Hogstrand, C., Haux, C., 1991. Binding and detixification of heavy metals in lower vertebrates with reference to metallothionein. Comp. Biochem. Physiol. 100, 137-141.

25. Hung, T.C., Meng, P.J., Han, B.C., Chuang, A., Huang, C.C., 2001. Trace metals in different species of mollusca, water and sediments from Taiwan coastal area. Chemosphere 44, 833-841. doi:10.1016/S0045-6535(00)00491-4

26. Jović, M., Stanković, S., 2014. Human exposure to trace metals and possible public health risks via consumption of mussels Mytilus galloprovincialis from the Adriatic coastal area. Food Chem. Toxicol. 70, 241-251. doi:10.1016/j.fct.2014.05.012

27. Joy, M., Chakraborty, K., 2017. Nutritional qualities of the low-value bivalve mollusks Paphia malabarica and Villorita cyprinoides at the Estuarine waters of the Southwestern Coast of India. J. Aquat. Food Prod. Technol. 26, 54-70. doi:10.1080/10498850.2015.1092486

28. Kaladharan, P., Prema, D., Valsala, K., Leelabhai, K., Rajagopalan, M., 2005. Trends in heavy metal concentrations in sediment, finfishes and shellfishes in inshore waters of Cochin, southwest coast of India. J. Mar. Biol. Assoc. India 47, 1-7.

29. KrishnaKumari, L., Kaisary, S., Rodrigues, V., 2006. Bio-accumulation of some trace metals in the short-neck clam Paphia malabarica from Mandovi estuary, Goa. Environ. Int. 32, 229-234. doi:10.1016/j.envint.2005.08.016

30. KrishnaKumari, L., Nair, V.R., Moraes, C.M., 1992. Bio-accumulation of Copper, Zinc, Iron and Manganese in oyster Saccostrea cucullata, snail Cerithium rubus and clam Tellina angulata from the Bombay coast. J. Coast. Res. 8, 347-354.

31. Krishnakumar, P.K., Bhat, G.S., Vaidya, N.G., Pillai, V.K., 1998. Heavy metal distribution in the biotic and abiotic matrices along Karnataka coast, west coast of India. Indian J. Mar. Sci. 27, 201-205.

32. Krishnakumar, P.K., Pillai, V.K., Valsala, K.K., 1990. Bioaccumulation of trace metals by marine flora and fauna near a caustic soda plant (Karwar, India). Indian J. Fish. 37, 129- 137.

33. Krishnakumar, P.K., Sasikumar, G., Bhat, G.S., Asokan, D.P.K., 2006. Biomarkers of environmental contaminants in field population of green mussel (Perna viridis) from Karnataka-Kerala coast (South West coast of India). Ecotoxicology 15, 347-352. doi:10.1007/s10646-006-0071-7

34. Krishnan, S., Chakraborty, K., Vijayagopal, P., 2019. Nutritional profiling of selected species of edible marine molluscs from the south-west coast of India. Indian J. Fish. 66, 56-63. doi:10.21077/ijf.2019.66.1.80079-08

35. KSCSTE., 2007. State of the environment report of Kerala 2007, Volume I. http://moef.gov.in/wp-content/uploads/2018/04/Kerala_SoE2007V1_0.pdf.

36. Lakshmanan, P.T., Nambisan, P.N.K., 1983. Seasonal variations in trace metal content in bivalve molluscs, Villorita cyprinoides var. cochensis (Hanley), Meretrix casta (Chemnitz) \& Perna viridis (Linnaeus). Indian J. Mar. Sci. 12, 100-103.

37. Lakshmanan, P.T., 1988. Heavy metals in commercially processed molluscan products in relation to quality, in: National Seminar on Shellfish Resources and Farming. pp. 417- 422.

38. Maanan, M., 2008. Heavy metal concentrations in marine molluscs from the Moroccan coastal region. Environ. Pollut. 153, $176-183$. doi:10.1016/j.envpol.2007.07.024

39. McConchie, D.M., Lawrance, L.M., 1991. The origin of high Cadmium loads in some bivalve molluscs from Shark Bay, Western Australia: A new mechanism for Cadmium uptake by filter feeding organisms. Arch. Environ. Contam. Toxicol. 21, 303-310.

40. MFR., 1985. Malaysian Food Regulations.

41. Mohamed, K.S, Kripa, V., Asokan, P.K., Sasikumar, G., Venkatesan, V., Sharma, J., Alloycious, P.S., Chinnadurai, S., Sharma, R., Prema, D., 2016. Development of bivalve farming as a source of income generation for women's self-help groups in coastal India. In: FAO-Sustainable intensification of aquaculture in the Asia-Pacific region (ed Miao, and Lal KK), p. 153. Bangkok, Thailand.

42. Mohamed, K.S., Asokan, P.K., Sasikumar, G., Kaladharan, P., Kripa, V., Sanil, N.K., Padua, S., Prema, D., Vidya, R., Jenni, B., Sajikumar, K.K., Anasukoya, A., Alloycious, P.S., Joy, J., Venkatesan, V., 2019. Guidance for good mussel farming practices in India based on a case-study from Kerala. CMFRI Marine Fisheries Policy Series No. 10. 
43. MPEDA., 2018. The Marine Products Export Development Authority Annual Report. Kochi, Kerala, India. Retrieved from https://www.mpeda.gov.in/MPEDA/annual_reports.php\#.

44. OSPAR., 2015. Status and trend for heavy metals (Mercury, Cadmium, and Lead) in fish and shellfish. https://oap.ospar.org/en/osparassessments/intermediate-assessment- 2017/pressures-human-activities/contaminants/metals-fish-shellfish/.

45. Otchere, F.A., 2003. Heavy metals concentrations and burden in the bivalves (Anadara (Senilia) senilis, Crassostrea tulipa and Perna perna) from lagoons in Ghana: Model to describe mechanism of accumulation/excretion. African J. Biotechnol. 2, 280-287.

46. Páez-Osuna, F., Frías-Espericueta, M.G., Osuna-López, J.I., 1995. Trace metal concentrations in relation to season and gonadal maturation in the oyster Crassostrea iridescens. Mar. Environ. Res. 40, 19-31. doi:10.1016/0141-1136(94)00004-9

47. Parvez Al-Usmani, S.M., Jagtap, T.G., Patil, D.N., 2015. Trace metals in water, sediment and bivalves of a tropical estuary, west coast of India. Mar. Pollut. Bull. 99, 328-331. doi:10.1016/j.marpolbul.2015.07.036

48. Patra, P., Mohandass, C., Chakraborty, P., 2019. Snapshot of environmental condition in different tropical estuarine systems by using S. cucullata (an edible oyster) as bioindicator. Environ. Sci. Pollut. Res. 26, 11342-11354. doi:10.1007/s11356-019-04564-w

49. Pinto, R., Acosta, V., Segnini, M.I., Brito, L., Martínez, G., 2015. Temporal variations of heavy metals levels in Perna viridis, on the ChacopataBocaripo lagoon axis, Sucre State, Venezuela. Mar. Pollut. Bull. 91, 418-423. doi:10.1016/j.marpolbul.2014.09.059

50. Ramasamy, E.V., Jayasooryan, K.K., Chandran, M.S.S., Mohan, M. (2017). Total and methyl mercury in the water, sediment, and fishes of Vembanad, a tropical backwater system in India. Environ. Monit. Assess. 189, 130. https://doi.org/10.1007/s10661-017-5845-2.

51. Ragi, A.S., Leena, P.P., Cheriyan, E., Nair, S.M., 2017. Heavy metal concentrations in some gastropods and bivalves collected from the fishing zone of South India. Mar. Pollut. Bull. 118, 452-458. doi:10.1016/j.marpolbul.2017.03.029

52. Raveenderan, R., Sujatha, C.H., 2011. Quantization of specific trace metals in bivalve, Villorita Cyprinoides var cochinensis in the Cochin estuary. Indian J. Mar. Sci. 40, 424- 429.

53. Ribeiro, C.A.O., Schatzmann, M., de Assis, H.C.S., Silva, P.H., Pelletier, E., Akaishi, F.M., Evaluation of Tributyltin subchronic effects in tropical freshwater fish (Astyanax bimaculatus, Linnaeus, 1758). Ecotoxicol. Environ. Safety 51(3), 161-167167, 161-167.

https://doi.org/10.1006/eesa.2001.2121.

54. Rivonker, C.U., Parulekar, A.H., 1998. Seasonal variation of major elements (Ca, Mg) and trace metals (Fe, Cu, Zn, Mn) in cultured mussel Perna viridis L. and seawater in the Dona Paula Bay, Goa. Indian J. Mar. Sci. 27, 411-415

55. Saha, M., Sarkar, S.K., Bhattacharya, B., 2006. Interspecific variation in heavy metal body concentrations in biota of Sunderban mangrove wetland, northeast India. Environ. Int. 32, 203-207. doi:10.1016/j.envint.2005.08.012

56. Sankar, T. V., Zynudheen, A.A., Anandan, R., Viswanathan Nair, P.G., 2006. Distribution of organochlorine pesticides and heavy metal residues in fish and shellfish from Calicut

57. region, Kerala, India. Chemosphere 65, 583-590. doi:10.1016/j.chemosphere.2006.02.038

58. Sarkar, S.K., Cabral, H., Chatterjee, M., Cardoso, I., Bhattacharya, A.K., Satpathy, K.K., Alam, M.A., 2008. Biomonitoring of heavy metals using the bivalve molluscs in

59. Sunderban mangrove wetland, northeast coast of Bay of Bengal (India): Possible risks to human health. Clean - Soil, Air, Water 36, $187-194$. doi:10.1002/clen.200700027

60. Sasikumar, G., Krishnakumar, P.K., Bhat, G.S., 2006. Monitoring trace metal contaminants in green mussel, Perna viridis from the coastal waters of Karnataka, southwest coast of India. Arch. Environ. Contam. Toxicol. 51, 206-214. doi:10.1007/s00244-005-0055-2

61. Sasikumar, G., Krishnamoorthy, M., Krishnakumar, P.K., Bhat, G.S., 2011. Accumulation of trace metals in green mussel Perna viridis in the shellfish harvesting environment along southern Karnataka coast. Indian J. Fish. 58, 53-58.

62. Satheeswaran, T., Yuvaraj, P., Damotharan, P., Karthikeyan, V., Jha, D.K., Dharani, G., Balasubramanian, T., Kirubagaran, R., 2019. Assessment of trace metal contamination

63. in the marine sediment, seawater, and bivalves of Parangipettai, southeast coast of India. Mar. Pollut. Bull. $149,110499$. doi:10.1016/j.marpolbul.2019.110499

64. Seethal Lal, S., Jaya, D.S., Williams, S. Trace metal pollution on water, sediment and fish fauna of Vattakkayal, a part of Ashtamudi Lake in South India. J. Environ. Chem. Ecotoxicology, (in press).

65. Seetharaman, P., Sarma, K., George, G., Krishnan, P., Roy, S.D., Sankar, K., 2015. Impact of coastal pollution on microbial and mineral profile of edible oyster (Crassostrea

66. rivularis) in the coastal waters of Andaman. Bull. Environ. Contam. Toxicol. 95, 599-doi:10.1007/s00128-015-1601-x

67. Senthilnathan, S., Balasubramanian, T., Venugopalan, V.K., 1998. Metal concentration in mussel Perna viridis (Bivalvia/Anisomyaria) from some parts in southeast coast of India. Indian J. Geo-Marine Sci. 27, 206-210.

68. ShibiniMol, P.A., Raveendran, R., Sujatha, C.H., 2015. Elucidation of contaminant-induced toxic responses in the biota of Lake Vembanad, Kerala, India. Hum. Ecol. Risk Assess. 21, 1576-1592. doi:10.1080/10807039.2014.960722

69. Sivaperumal, P., Sankar, T. V., Viswanathan Nair, P.G., 2007. Heavy metal concentrations in fish, shellfish and fish products from internal markets of India vis-a-vis international standards. Food Chem. 102, 612-620. doi:10.1016/j.foodchem.2006.05.041

Page 11/13 
70. Sneddon, J., Vicent, M.D., 2008. ICP-OES and ICP-MS for the determination of metals: application to oysters. Anal. Letters. 41, $1291-1303$. https://doi.org/10.1080/00032710802013991.

71. Sruthi, S.N., Shyleschandran, M.S., Mohan, M., Ramasamy, E.V., 2018. Distribution of priority pollutants in the sediment of Vembanad Estuary, Peninsular India. Mar. Pollut. Bull. 133, 294-303. https://doi.org/10.1016/j.marpolbul.2018.05.033.

72. Swaileh, K.M., 1996. Seasonal variations in the concentrations of $\mathrm{Cu}, \mathrm{Cd}, \mathrm{Pb}$ and Zn in Arctica islandica L. (Mollusca: Bivalvia) from Kiel Bay, Western, Baltic Sea. Mar. Pollut. Bull. 32, 631-635. doi:10.1016/0025-326X(96)00026-4

73. US Environmental Protection Agency, 2011. Exposure Factors Handbook: 2011 Edition. U.S. Environ. Prot. Agency EPA/600/R-, 1-1466. doi:EPA/600/R-090/052F

74. Varshney, R.K., 2003. Studies on the bioaccumulation and effect of environmental stress on the green mussel, Perna viridis (Linnaeus, 1758). Central Institute of Fisheries Education.

75. WHO, 1993. International Programme on Chemical Safety Toxicological evaluation of certain food.

76. Yahiya, M., Mohan, K.J., Miranda, M., 2018. Trace metal accumulation in marine molluscs (Perna indica \& Bursa sp) along the southern coast of Kerala , India. Int. J. Fish. Aquat. Stud. 6, 332-335.

77. Yap, C.K., Cheng, W.H., Karami, A., Ismail, A., 2016. Health risk assessments of heavy metal exposure via consumption of marine mussels collected from anthropogenic sites. Sci. Total Environ. 553, 285-296. doi:10.1016/j.scitotenv.2016.02.092

\section{Figures}
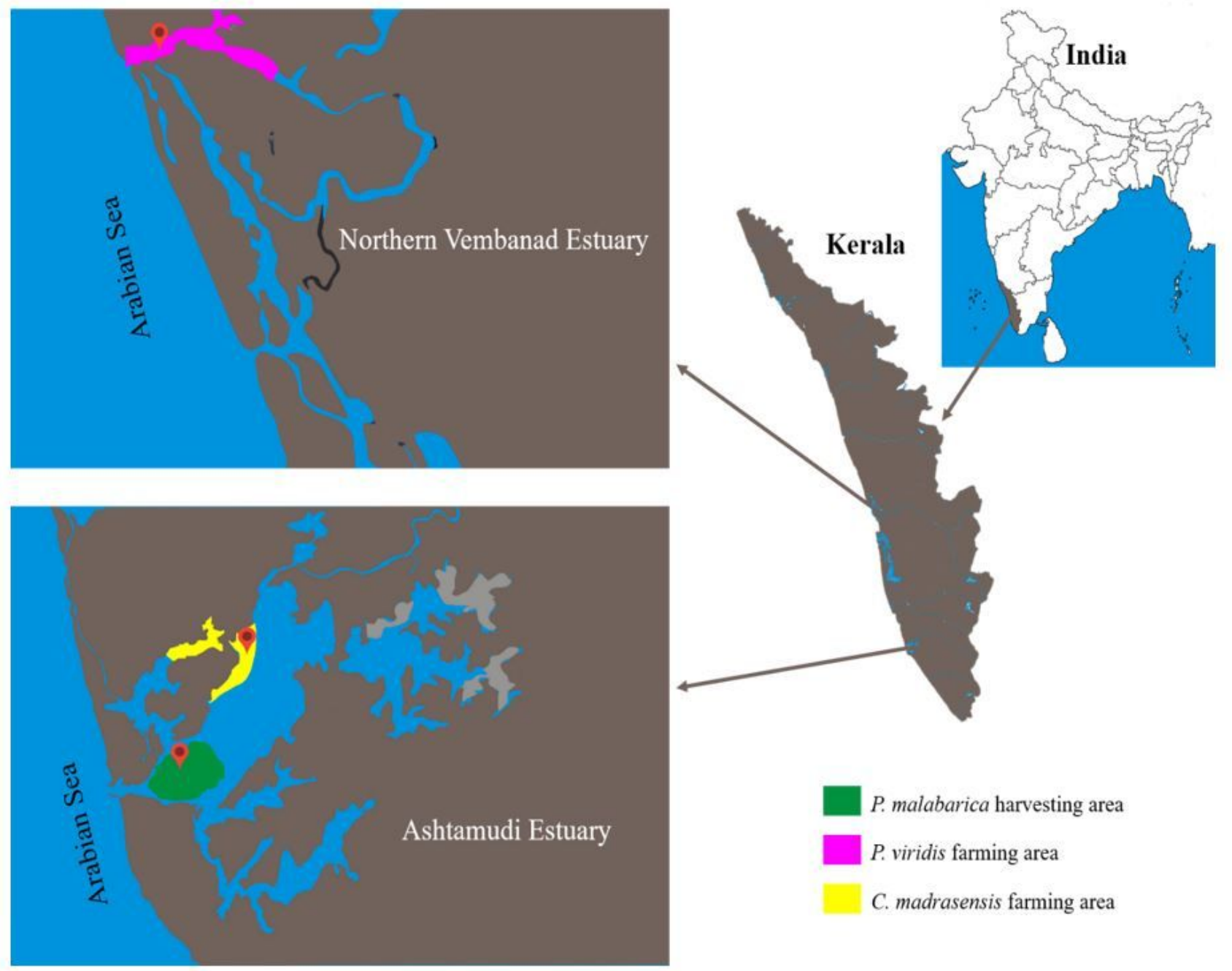

\section{Figure 1}

Map of the Ashtamudi and northern Vembanad estuaries showing the sampling points for the three shellfish species monitored. Note: The designations employed and the presentation of the material on this map do not imply the expression of any opinion whatsoever on the part of 
Research Square concerning the legal status of any country, territory, city or area or of its authorities, or concerning the delimitation of its frontiers or boundaries. This map has been provided by the authors. 